
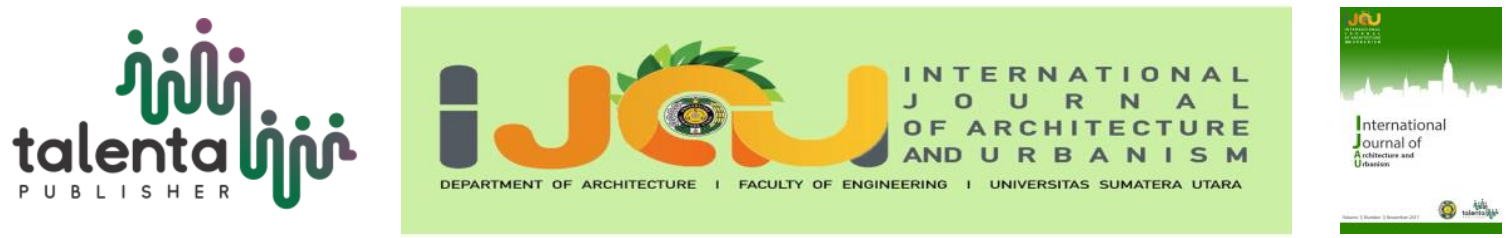

\title{
Study of Physical Traces Toward Activities and Behaviour of Public Open Space Users (Case Study: Merdeka Square of Binjai City)
}

\author{
Novrial $^{*}$, Marina Dwi Avisha ${ }^{1}$ \\ ${ }^{1}$ Architecture Department, Faculty of Engineering, Universitas Sumatera Utara, Medan, Indonesia
}

\begin{abstract}
Merdeka Square of Binjai City is one of the public open spaces in Binjai City, which has a variety of activities and various types of public open user behavior. Some users of public open space behavior do not use the square facilities by the function of public open spaces. This study aims to identify the physical traces left by the users, to know the activities and behavior of users of Merdeka Square in Binjai City. The method used is a literature study, direct observation accompanied by behavioral mapping and described descriptively with a qualitative approach. The results showed that the behavior of users did not use the facilities in accordance with their functions, such as using a badminton court as a place to play skateboard, and the activities of users who left a physical traces at the Merdeka Square in Binjai City, such as sitting and relaxing in the grass in the middle of the field. The physical traces left by the users of the Merdeka City Square in Binjai, among others, is damage to the grass area in the middle of the field and damaged sidewalk barriers.
\end{abstract}

Keywords: activities, physical traces, public open space, user behavior

\section{Introduction}

Merdeka Square of Binjai City is located in the Binjai City area which is one of the public open spaces in the middle of Binjai City, which can be accessed easily by the city and people from our town and has a variety of activities and various types of public open space user behavior. Activities that occur in Merdeka Square of Binjai are in the form of non-formal activities such as sports, recreation, trading, arts and cultural, social interaction, and formal activities such as state ceremonies, religious ceremonies, and political (campaigns).

\footnotetext{
*Corresponding author at : Departement of Architecture, faculty of Engineering, Universitas Sumatera Utara, Jalan Perpustakaan, Building J07, Medan 20155, Indonesia

E-mail address: anovrial@yahoo.com.sg
} 


\section{Literature Study}

\section{Activity}

Activities as action or busyness [1]. Suggested the existence of passive and active involvement in the use of public space. These two forms of experience occur as a result of the interaction process, where public space users can interact in different ways. Social interaction can occur in the form of passive activities such as just sitting enjoying the atmosphere or observing the situation and can also occur actively by talking with other people about a topic or even doing a joint activity [2].

\section{Behavior}

People and their behavior are part of a whole system that includes place and environment, such that behavior and environment cannot be empirically separated. That is to say, human behavior always happens in a place, and they cannot be full evaluated without considering the environmental influence [3].

The environment influences human behavior. People tend to occupy a place that is usually occupied even though the place is not a place to sit, Human behavior that affects the environment. When people tend to choose shortcuts, they think they are closest to passing a rotating pedestrian. So that the person unconsciously made his path even though a pedestrian was provided [4]. Human factors that influence the principles of building user behavior include: (a) Basic needs, (b) Age, (c) Gender [5].

\section{The Relationship between Architecture, Environment, and Behavior}

Space as one of the components of architecture is important in the discussion of the study of environmental and behavioral architecture relations because of its function as a forum for activities. Behavior operationalized as human activities that require setting or container of activity in the form of space. Various human activities are interrelated in one system of activities [6].

\section{Behavior Mapping}

Behavior mapping described in the form of sketches or diagrams about an area where humans carry out various activities. There are two ways to conduct behavioral mapping, namely: (a) Mapping by Place. This technique is used to find out how humans or groups of people use, use, and accommodate their behavior at a certain time,(b) Mapping by Perpetrators. This technique emphasizes human movement in a certain period, where this technique relates to not only one place or location but several places/locations. In this technique, the researcher is dealing with someone who is specifically observed [7]. 


\section{Public Open Space}

Public open space is one of the facilities needed by the city. Public open space is a land that is not built with certain uses; public open space is not occupied by buildings and can be felt if it has a barrier around it. Open space has the function and quality seen from its composition [8]. Public open spaces have functioned as nodes and communicative means well as social ties to create interactions between community groups and as a daily gathering place and on special occasions [9]. If the quality of the public open space is good, then outdoor activities such as recreational and social activities can be carried out properly, the user takes longer because space invites the user to stop, sit down, eat, play, and so on [10].

\section{Physical Traces}

The physical traces left behind can be known by paying attention to the physical environment around to find previous activities. Unconsciously, humans will leave traces in every activity, such as footprints on the ground or hand marks on the floor. On the other hand, physical traces can change human behavior in the environment; for example, when someone enters a new building, of course, his behavior will be different from when he was in the previous building [11]. This says that if the appearance of the environment is not able to follow the pattern of behavior, then humans will not be able to follow the goal [12].

Physical Traces is a research method in human behavior that aims to find out traces that can be a reference for improvement in design. Physical traces can also be used as an analysis in the design of an environment and assess whether the environment is functioning effectively [13].

\section{Methodology of Research}

The research was carried out through descriptive methods with a qualitative approach. Data collection techniques are carried out by observation, behavior mapping, and interviews.

\section{Analysis Phases}

(1) Determine objects and limitations of research: (a) Research is limited to the behavior of users of public open spaces with 10-60 years old users, (b) Research on user's behavior will only be carried out at the Merdeka Square in Binjai City, (c) The time of research observation is done in the morning at $08.00-10.00$ and on Sunday and evening at 16.00-18.00 on Monday to Saturday. (2) Search literature review. Conduct a literature review as a direction in conducting research. (3) Make observations and interviews: (a) Make direct observations to the field and documentation, (b) Interview users of Merdeka Square and conduct behavioral mapping. (4) Make an analysis: (a) Determine zones in Merdeka Square, (b) Analyze the results of observations and interviews adjusted to the existing theories. (5) Make conclusions. 


\section{Location of Research}

The research location is in Binjai City, which is often visited by the community located in Tangsi Village, Binjai Kota District, Binjai City, North Sumatra. The research location is only $4.1 \mathrm{~km}$ from the center of Binjai City via Sultan Hasanuddin street. Based on its astronomical location, Merdeka Square of Binjai City is located at 3 degrees latitude and 98 degrees longitude, and Merdeka Square of Binjai City has an area of about 1.5 hectares. The research location is located in Merdeka Square, Binjai City, bordering with Veteran Street on the North and West. While the east is bordered with Jendral Sudirman street, and the South is bordered by Jendral Gatot Subroto street (Figure 1).

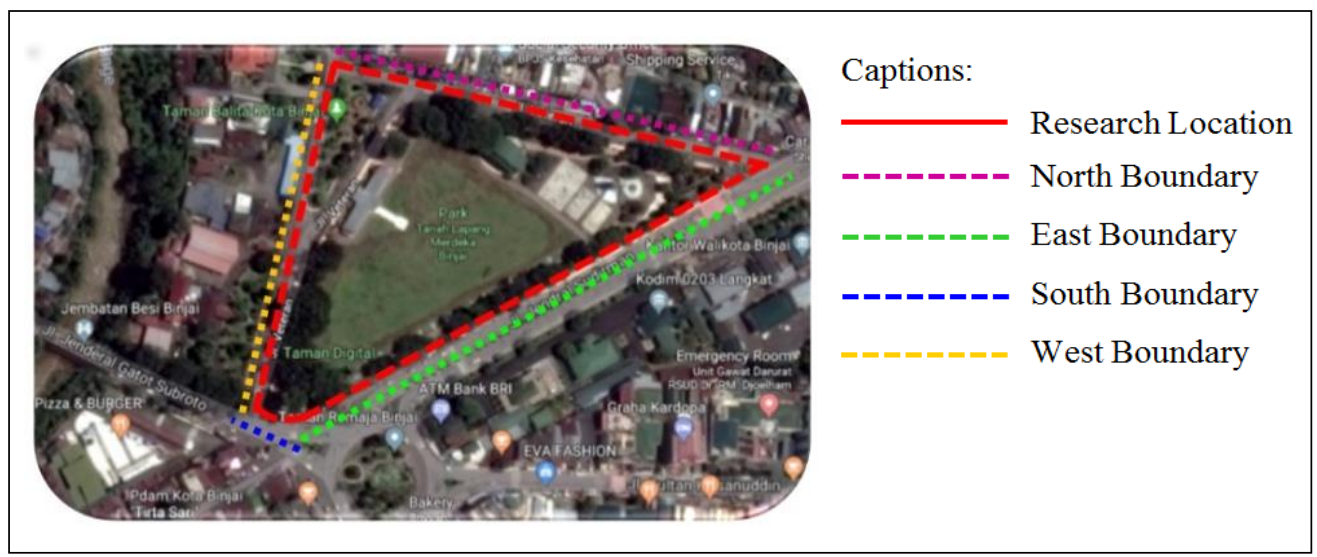

Figure 1. Research Location in Merdeka Square of Binjai City

(Source: Google Earth, (2018)

\section{Result and Discussion}

\section{Merdeka Square of Binjai City}

Merdeka Square is surrounded by commercial buildings such as shop house/stalls and government buildings such as the Office of the Mayor of Binjai, Military District Command 0203 Langkat, Department of Highways, etc. Merdeka Square provides a variety of sports facilities and grass areas in the middle of a large field that can be used as a place to hold an event from the Binjai City Government. Merdeka Square of Binjai City has a Pendopo facility which is often used for the Binjai City Government event, Open Stage which is often used in arts and cultural events, Digital Parks for users of the Merdeka Square in Binjai City as a sitting area and also a Toddler Park which is provided for children children who have several children's game. Some of the sports facilities provided at Merdeka Square are jogging tracks, gym facilities, rock climbing, basketball courts, and volleyball/badminton courts.

\section{Active Zone of Merdeka Square of Binjai City Users}

Merdeka Square has an active activity zone used by Merdeka Square users and has an activity zone that is less active for users of Merdeka Field. Based on the results of observations of the research, it can be seen 5 (five) zones that are actively used by users, namely: 


\section{Grass Area in Middle of The Field}

This zone is often used as a place of recreation to relax and sports venues such as playing football by users. When the Merdeka Field held an event, the zone was used for tent, event stage, and four wheels parking (Figure 2).

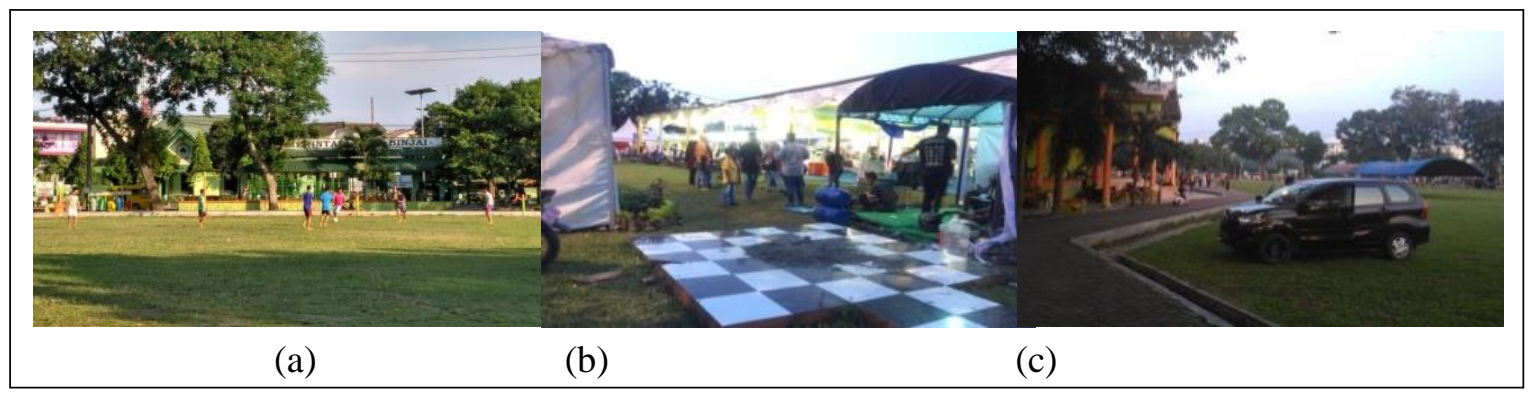

Figure 2. Playing Ball (a) Event Tent (b) Four WheelsParking (c)

\section{Jogging Track}

This zone is often used as a place for users to jogging. However, some of the users use it as a cycling area. When the Merdeka Square held an event, this area will be used as a two wheels parking (Figure 3).

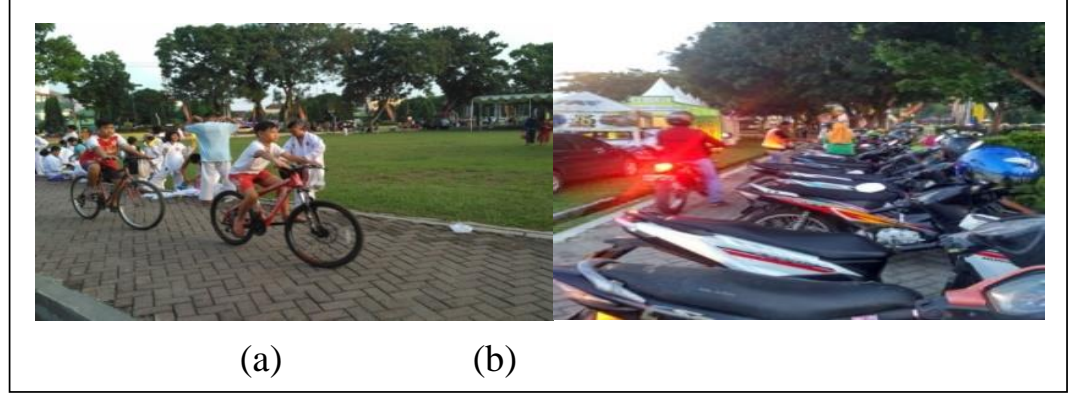

Figure 3. Playing a Bike (a) Two Wheels Parking (b)

\section{Sports Field}

Basketball Court. This zone is often used as a place to play basketball by users. However, this area is often used as a place to play roller skates (Figure 4).

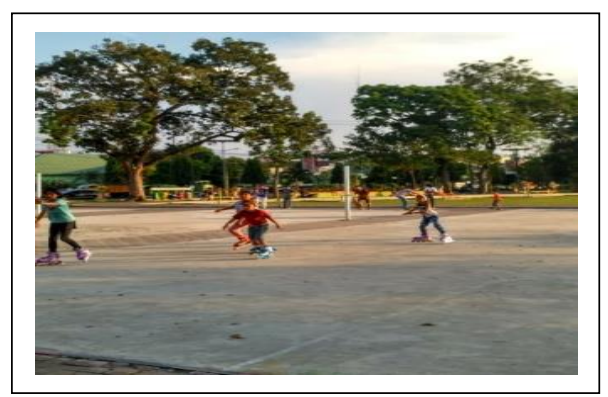

Figure 4. Playing Roller skate

Badminton Court. This zona has often used a place to play badminton by the user. However, this area is often a place to play skateboard (Figure 5). 


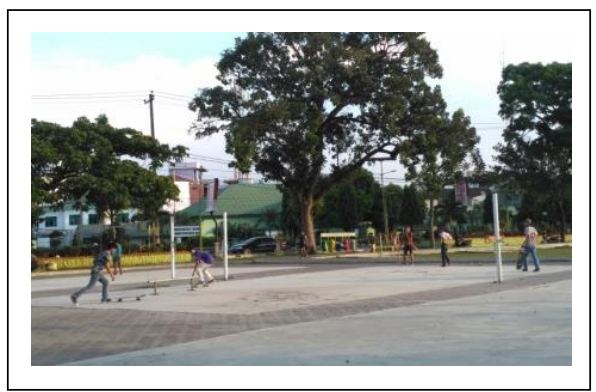

Figure 5. Playing Skateboard

\section{Toddlers Area}

This zone is certainly used by many children to play. But some teenagers often use this area as a relaxing area and parents who accompany their children to play (Figure 6).

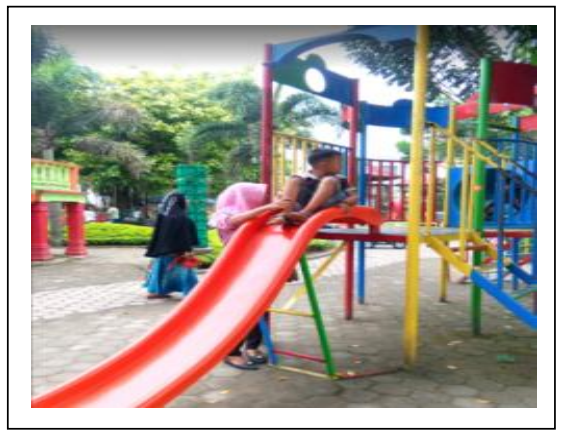

Figure 6. Children's Play Area

\section{Conditions of Merdeka Square}

\section{Entrance}

Merdeka Square has two main lines and two additional lines. The main line of Merdeka Square is on the west side of Veteran street and two additional lines one is on the north side of Veteran street and the other on the west side of Veteran street (Figures 7).

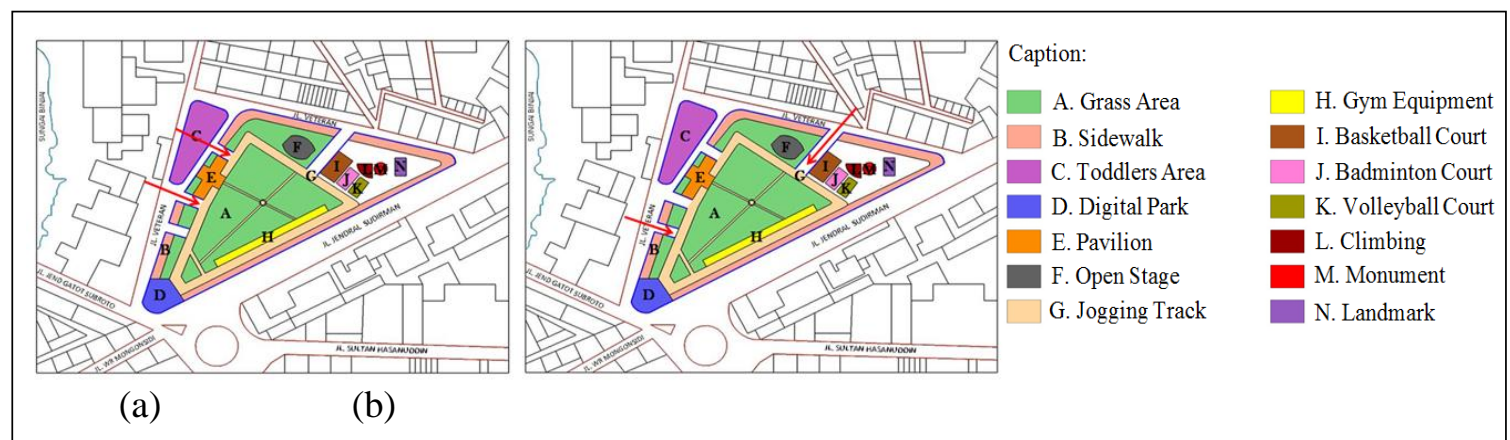

Figure 7. Main Entrance (a) Additional Entrance (b)

\section{Pavilion}

In general, Merdeka Square provides a pavilion as a place to use if there is an event or national day. The pavilion was designed at the end of Veteran road in the western part of the grass area of Merdeka Square. The right and left parts of the pavilion have been flanked by the main entry point of Merdeka Square (Figure 8). 


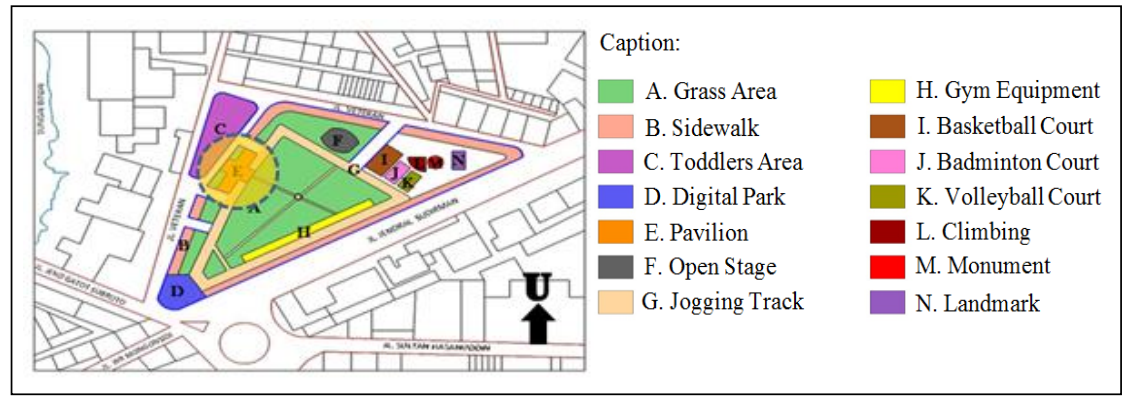

Figure 8. Pavilion

\section{Open Stage}

Merdeka Square provides an open stage at the end of Merdeka Square adjacent to a basketball court, the stands are designed high and quite wide and functioned as a stage in an event (Figure 9).

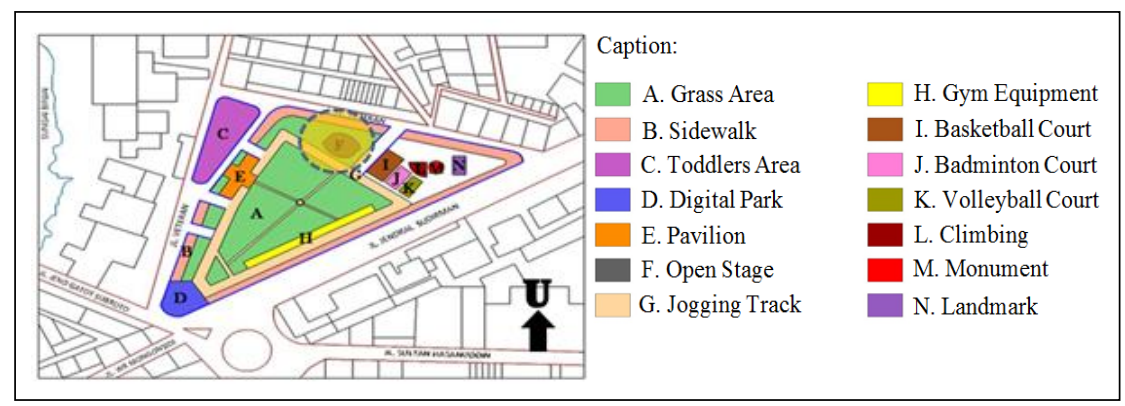

Figure 9. Open Stage

\section{Jogging Track}

Merdeka Square provides a jogging track as a facility from Merdeka Square. This jogging track is designed in the form of three following the shape of the Merdeka Square itself (Figure 10).

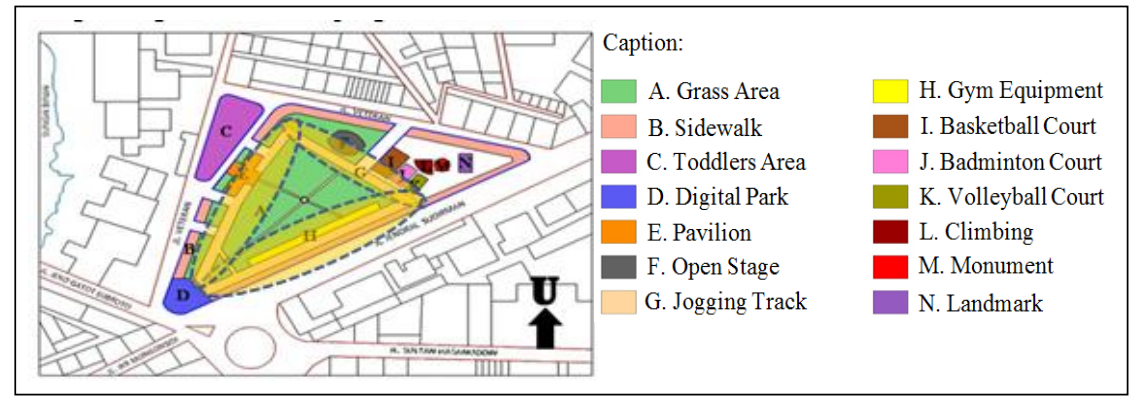

Figure 10. Jogging Track

\section{Gym Equipment}

Merdeka Square provides gym equipment as a Merdeka Square facility. The gym equipment area is designed to the side by side on one side of the jogging track area at the end of Merdeka Square, directed to Jendral Sudirman street. The positioning design of gym equipment is arranged one by one along the jogging track area (Figure 11). 


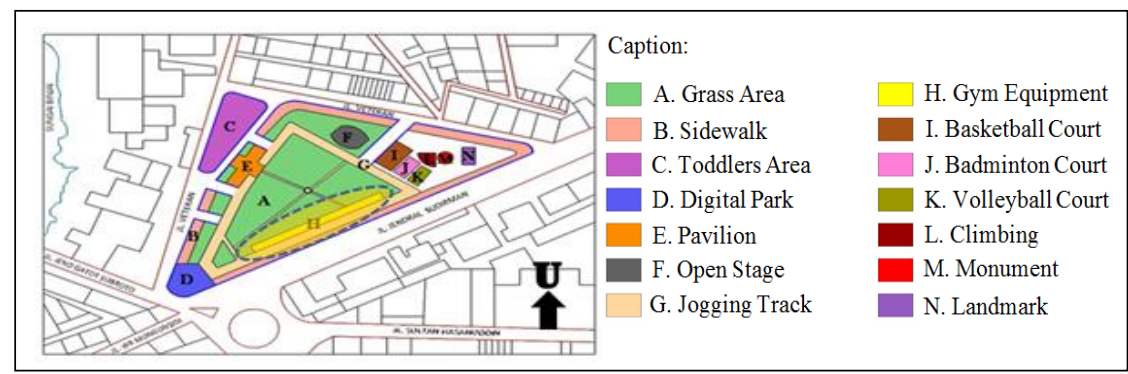

Figure 11. Gym Equipment

\section{Sports Field}

Basketball Court. Merdeka Square provides field facilities for sports, one of which is a basketball court. The basketball court is designed next to the badminton court area and is adjacent to the volleyball court area which faces the northern part of Veteran street (Figure 12).

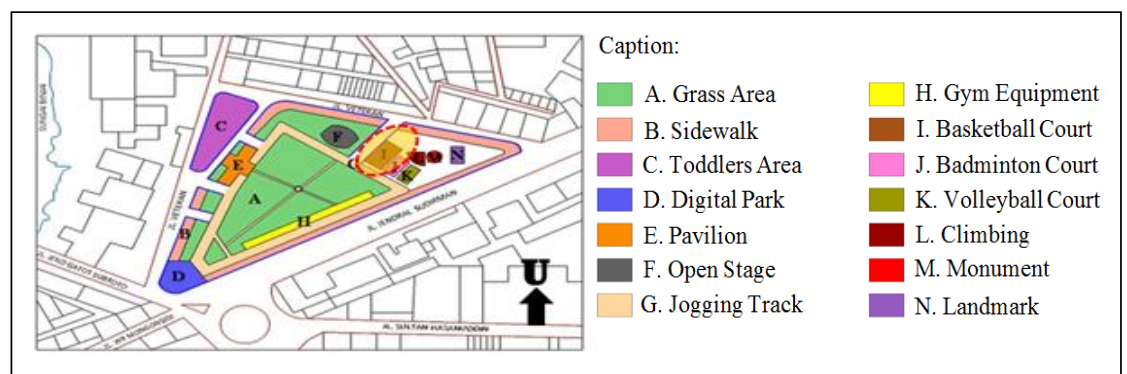

Figure 12. Basketball Court

Badminton Court. This badminton court is one of the sports facilities in Merdeka Square. This area is designed at the end of Merdeka Square and in the middle which is flanked by basketball courts and volleyball courts (Figure 13).

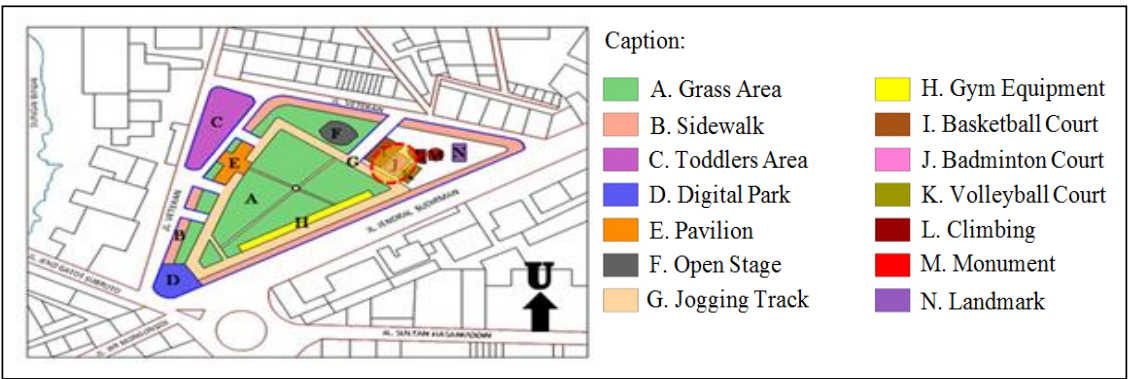

Figure 13. Badminton Court

Volleyball court. This volleyball court is one of the sports facilities at Merdeka Square. This area was designed at the end of Merdeka Square and was adjacent to the badminton court (Figure 14).

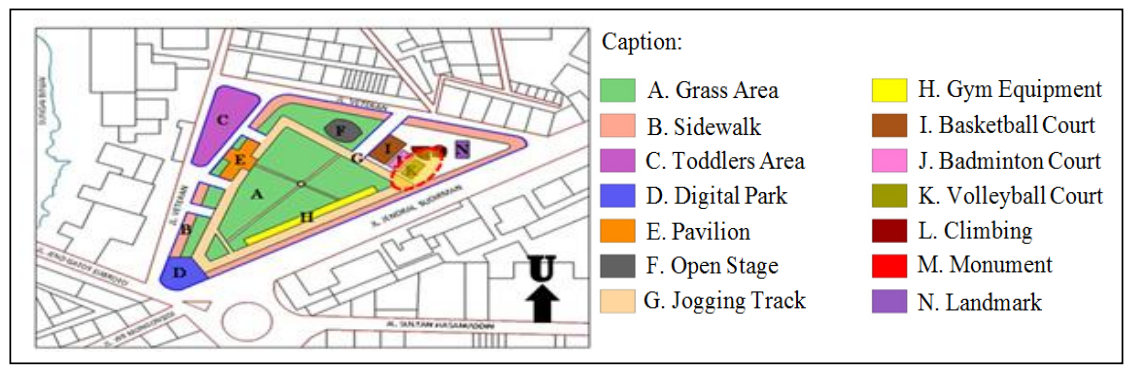

Figure 14. Volleyball Court 


\section{Park}

Digital Park. The digital park is a facility of Merdeka Square which was designed located at the end of the square facing the southern part; this area has a sitting area for users of Merdeka Square (Figure 15).

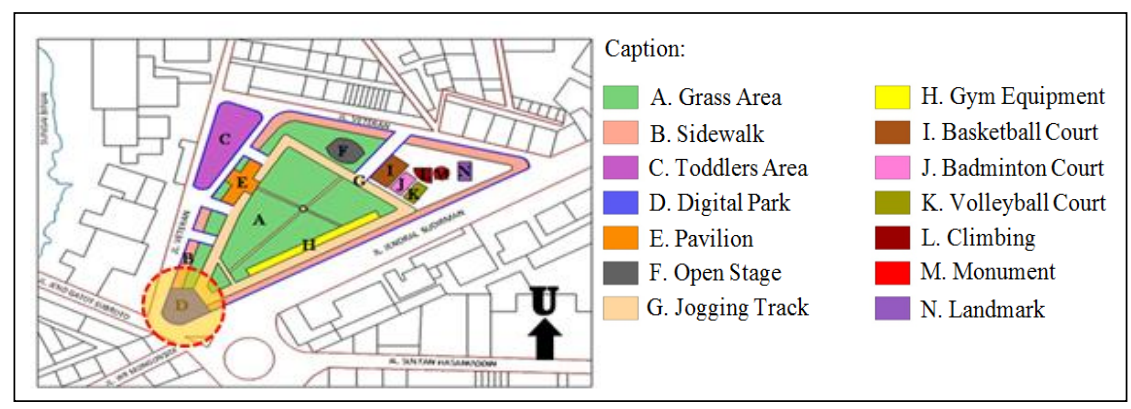

Figure 15. Digital Park

Toddler's Park. Toddlers Park is a facility of Merdeka Square which is designed to taste on the western part of Jalan Veteran at the end of the crossing with Merdeka Square. This area is available for children (Figure 16).

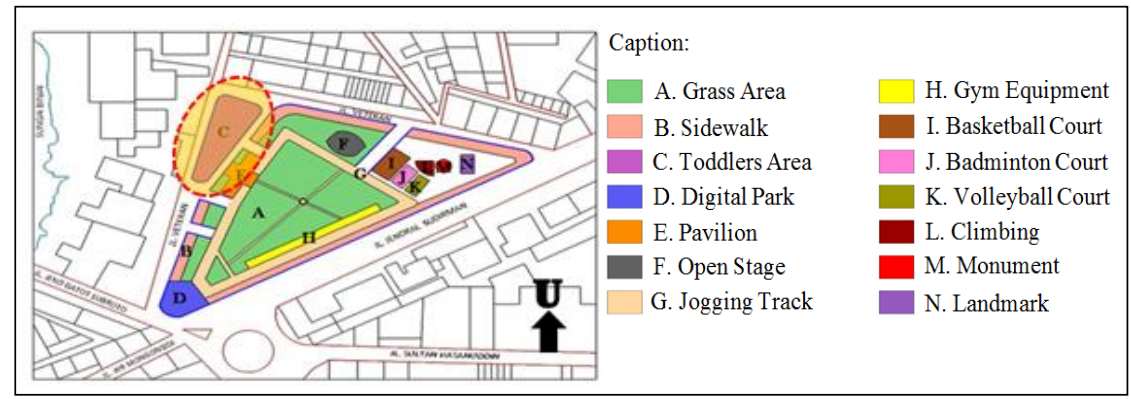

Figure 16. Toddler's Park

\section{Physical Trace}

The physical traces that are most often found in activities and behaviors used by users at Merdeka Square in Binjai City include :

\section{Grass Area in the Middle of the Field}

The number of activities carried out by users in the grass area in the middle of the field can be seen from several areas of grass that have been covered with soil again different from the grass in other areas.

Some of the activities carried out by users of Merdeka Square that are often found in the grass are sports above the grass area in the middle of the field seen in the picture and sit relax on the grass area in the middle of the field (Figure 17). 


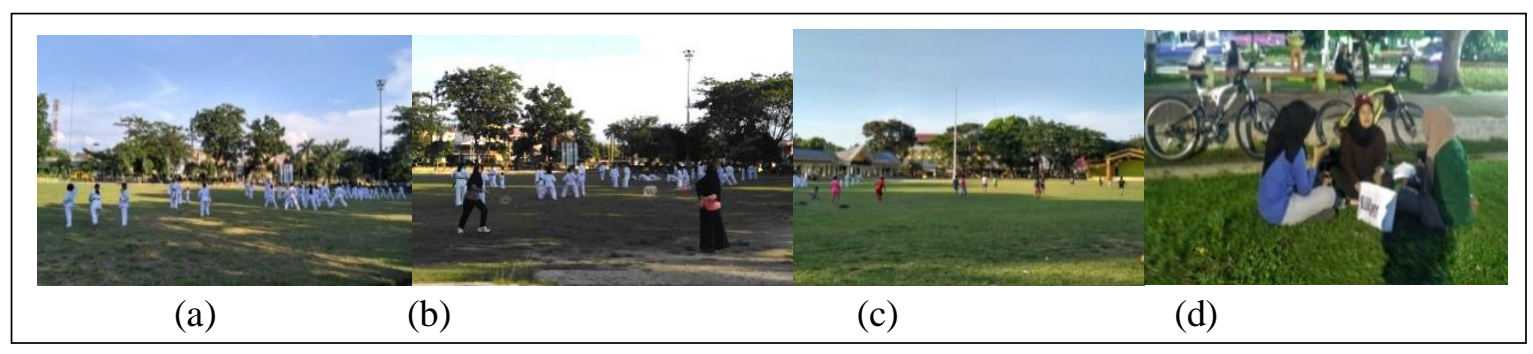

Figure 17. Martial Arts Exercises (a) Playing Badminton on Grass (b)

Playing Ball on Grass (c) Sitting Relaxing on Grass (d)

As for other causes, in an event that must be considered for the grass area in the middle of the field are tents installed and several parking vehicles going up the grass area in the middle of the field which causes the grass area in the middle of the field to be damaged and covered with land (Figure 18).

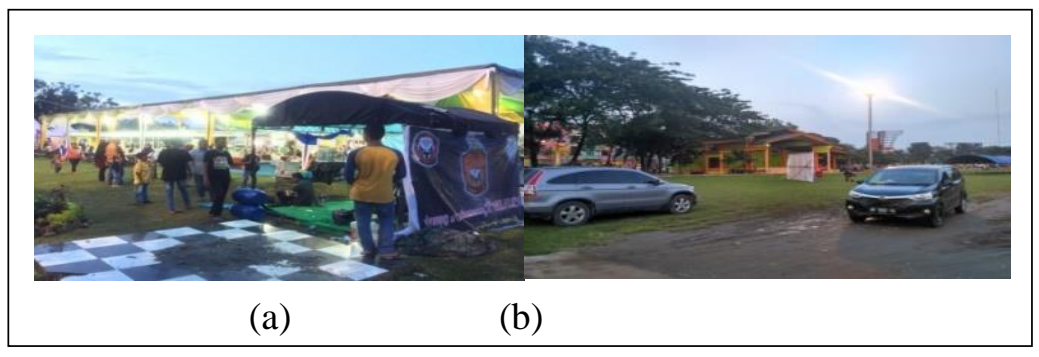

Figure 18. Tent of an Event Above the Grass Area in the Middle of the Field (a) Car Parking Above the Grass Area in the Middle of the Field (b)

\section{Jogging Track}

The number of activities carried out by users in the jogging track area. In addition to being used for jogging places, the jogging track area is used by users as a place for cycling, and some of the field users sit on the jogging track to relax. When Merdeka Square held an event several jogging track areas were used as two wheelsparking seen in the picture (Figure 19).

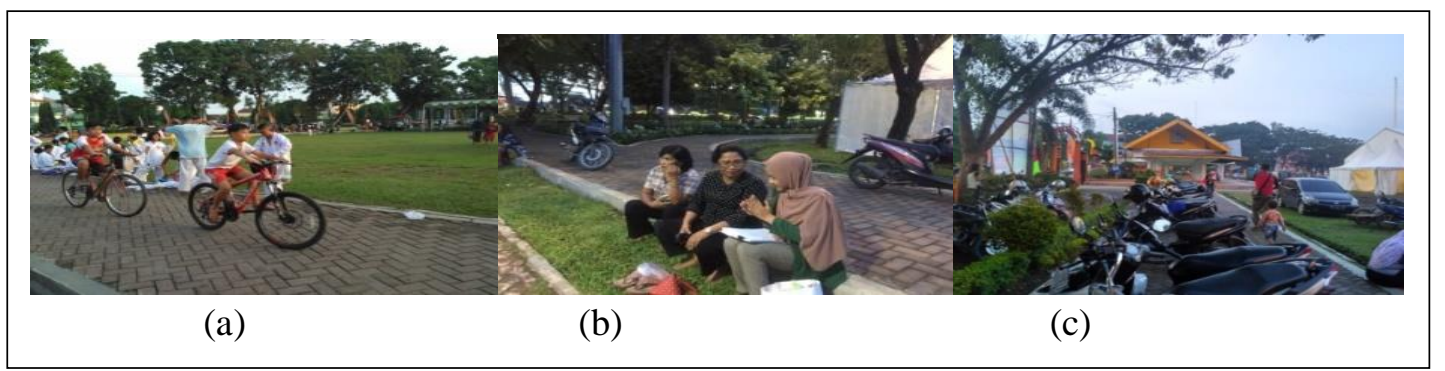

Figure 19. Playing Bicycle in Jogging Track Area (a) Relaxing in Jogging Track Area (b)Two Wheels Parking in the Jogging Track Area (c)

\section{Sports field}

Basketball Court. The Basketball court is used by users to play basketball. However, users from among children use the basketball court as a place to play roller skates seen in the picture. The considerations of users who trade sell and rent for roller skates in the basketball court area at 
Merdeka Square. However, this has caused users who want to use a field area that is by their functions (Figure 20).

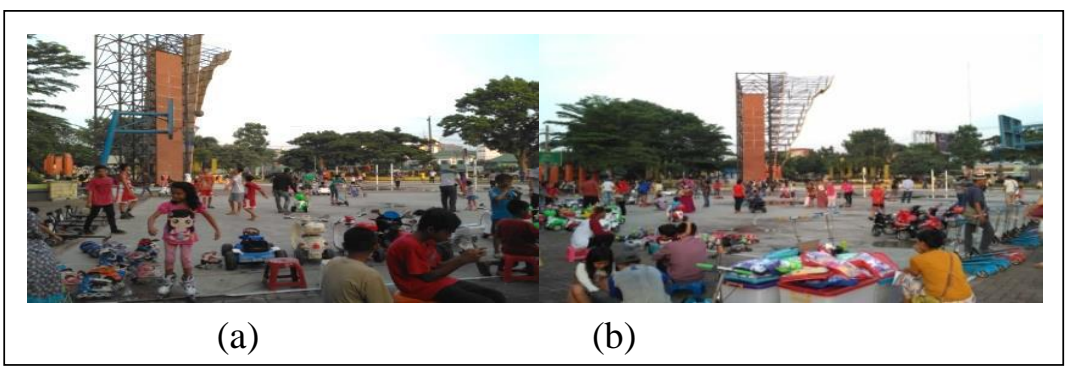

Figure 20. Children Playing Roller Skates on a Basketball Court (a)Basketball Court Conditions (b)

Badminton Court. Badminton court is used by users, not by its function. Badminton court is used for skateboarding by teenagers seen in the picture (Figure 21).

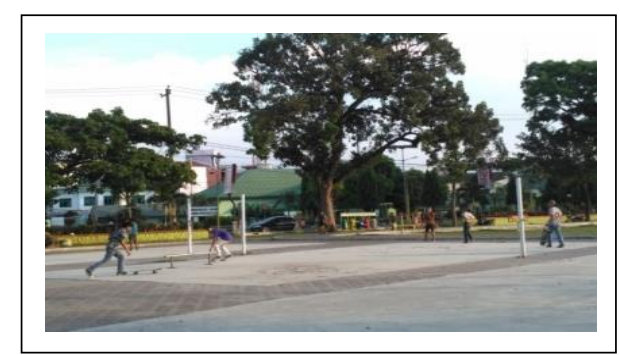

Figure 21. Children Playing Roller Skates on a Basketball Court

\section{Toddler's Park}

Users of this game area are not only among children, but teens also use it. Some parents accompanied their children to play, but they did not occupy the sitting area that had been provided and instead made use of some of the games available for resting in the picture (Figure 22).

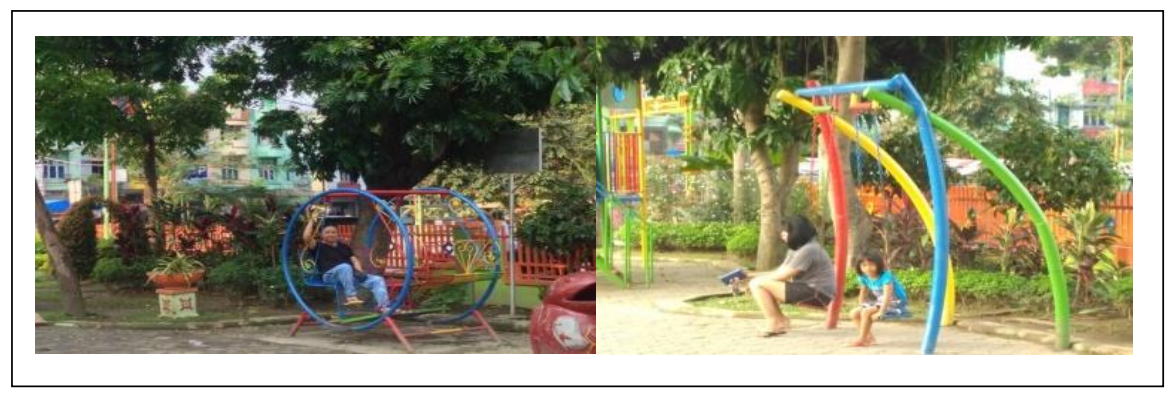

Figure 22. Parents Sitting in Children Area

\section{Conclusion}

The field is dominated by teenagers as a sports facility, place of interaction, social activities, and recreational needs. The number of activities in the afternoon compared to the morning. Some of the activities carried out by the field users leave many physical traces, including damaged grass because they are often occupied to relax, for sports activities and when holding an event the grass area is used as a four-wheeled parking lot, sidewalk barriers damaged by wheeled vehicles two who accidentally crossed, and some gym equipment damaged due to not being properly 
functioning by the user and no maintenance from the manager of Merdeka Square. Many users of the open space of Merdeka Square use space, not by its function.

\section{Acknowledgment}

Thank Allah Almighty who enabled me to complete this journal. And I would like to express my special thanks of gratitude to the Department of Architecture, Universitas Sumatera Utara which is provided insight and expertise that greatly assisted the research. This journal could not be complete without a great deal help from many people.

\section{REFERENCES}

[1] P. W.J.S, Kamus Besar Bahasa Indonesia, Jakarta: Balai Pustaka, 2002.

[2] M. Carmona, Public Places Urban Spaces : The Dimension of Urban Design, Burlington MA: Architectural Press, 2003.

[3] D. P. Duerk, Architectural Progamming : Information Management for Design, New York: Van Nostrand Reinhold, 1993.

[4] J. M. Laurens, Arsitektur dan Perilaku Manusia, Jakarta: PT Grasindo, 2004.

[5] J. C. Synder, Pengantar Arsitektur, Jakarta: Erlangga, 1989.

[6] Haryadi and S. B, Arsitektur, Lingkungan, dan Perilaku, Yogyakarta: Gadjah Mada University Press, 2010.

[7] R. Sommer and B. Sommer, Behavior Mapping : Practical Guide To Behavior Research, New York: Oxford University Press, 1980.

[8] M. Rapuano, D. P. P. Pirone and B. E. Wigginton, Open Space in Urban Design, Ohio: The Cleveland Development Foundation, 1964.

[9] Y. Pratiwi, "Transformasi Fungsi Ruang Terbuka Publik Di Perkotaan," Jurnal Arsitektur NALARs, vol. 15, pp. 63-72, 2016.

[10] Francis and C. Marcus, People Places : Design Guidelines for Urban Open Spaces, New York: Van Nostrand Reinhold, 1998.

[11] J. Ziesel, Inquiry by Design : Tools for Environment - Behavior Research, Cambridge: Cambridge University Press, 1980.

[12] J. Lang, Creating Architectural Theory, The Role of the Behavioral Sciences in Environmental Desig, New York: Van Nostrand Reinhold Company, 1987.

[13] W. Utami, "Children Physical Traces in Open Space," 2003. 